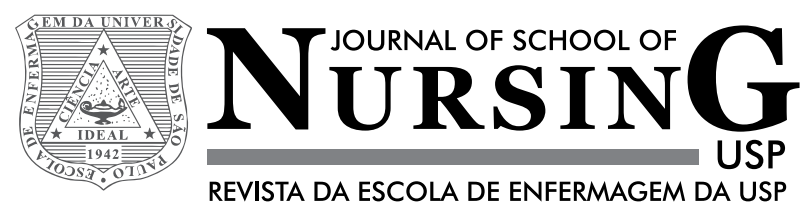

\title{
Family health nursing care: weaknesses and strengths in the Unified Health System*
}

\author{
O cuidar da enfermeira na saúde da família: fragilidades e \\ potencialidades no Sistema Único de Saúde \\ El cuidar de la enfermera en la salud de la familia: fragilidades \\ y potencialidades en el Sistema Único de Salud
}

\section{Simone Santana da Silva ${ }^{1}$, Marluce Maria Araújo Assis ${ }^{2}$}

\footnotetext{
* Extracted from the master's thesis, "Processo de cuidar da enfermeira na Estratégia Saúde da Família e suas interfaces com a rede do Sistema Único de Saúde em dois cenários da Bahia, Brasil: fragilidades e potencialidades", Departamento de Saúde, Universidade Estadual de Feira de Santana, 2013.

${ }^{1}$ Universidade do Estado da Bahia, Salvador, BA, Brazil.

${ }^{2}$ Universidade Estadual de Feira de Santana, Feira de Santana, BA, Brazil.
}

\section{ABSTRACT}

Objective: To analyze the weaknesses and strengths of nursing care in the Family Health Strategy and its interfaces with the Unified Health System network. Method: A qualitative study performed by means of semi-structured interviews and systematic observations, with the participation of a nursing team of 15 people from October of 2012 to January of 2013. Results: Strengths that were emphasized: the nurse's versatility in conducting users within the unit and the health system, therefore directly acting upon access to these services. The nurse is the main subject that participates in the care processes for the person, family and social groups. Weaknesses that were highlighted: fragile embracement and low resolution of users' and families' problems. Conclusion: The nursing care process in health units still lacks collective articulation, involvement of the team, and decentralization of the decisions.

\section{DESCRIPTORS}

Nursing Care; Family Health Strategy; Health Services Accessibility; Unified Health System; Public Health Nursing. 


\section{INTRODUCTION}

The Unified Health System (Sistema Único de Saúde, SUS) was designed as a Brazilian policy proposal in the Federal Constitution of 1988, which poses health as a fundamental human right, guaranteed by the sharing of responsibilities among the three governmental levels: states, cities and union ${ }^{(1)}$. The Health Care Networks $(\mathrm{HCN})$ in SUS are mechanisms to promote the right to health that integrate actions and services articulated in increasing levels of complexity, under the coordination of Primary Health Care (PHC), with the Family Health Strategy (FHS) as an intervention space ${ }^{(2)}$.

The HCN propose the articulation of systems, services and practices to compose territorial spaces consisting of specific populations with their individual and collective problems and needs. They are characterized by functions and objectives, involving health services and sectors of the society; they consider the flow of care that defines the entering and exiting of the users in the system, and also the governance system operated by the SUS leaders ${ }^{(2-3)}$.

In the work of the Family Health teams, the care process reveals a set of priority activities (individual and team care, health and service education, team coordination and procedures) and routine activities (home visits, meetings with the team and the managers, appointment scheduling and specialized tests, supervision, monitoring and evaluation of actions). These activities can impact directly on the offer of care to the service users.

In this sense, the place of the nurse in the health care team has historically been developed through managemental, educational and care actions. These actions have been undergoing changes over the years due to the needs that emerge from society ${ }^{(4-5)}$. These changes are driven by the expansion of the quality relationship, strengthened by qualified listening, establishment of linkages, and co-responsibility in defining the care of people requiring health services.

Nurses plays a decisive daily role in identifying the population's care needs as well as promoting and protecting the health of individuals in their different dimensions ${ }^{(6)}$. However, it is still necessary to define their object of work, from the articulation of care management in the Collective Health practices ${ }^{(5)}$.

Different studies ${ }^{(6-13)}$ on the subject address the nursing care in the FHS through practices that value educational activities $^{(8)}$. However, they reveal an overlapping of duties and fragile autonomy ${ }^{(9-11)}$.

The organizing role that triggers nursing care actions is recognized. Although they are guided by traditional knowledge of clinical practice, epidemiology and education, they directly affect the daily lives of health care services ${ }^{(4,11)}$.

Thus, this article discusses the process of nursing care in the FHS and its interfaces with the SUS network: weaknesses and strengths.

\section{METHOD}

This was a qualitative study performed by means of semi-structured interviews and systematic observations. The empirical field consisted of 11 (eleven) Family Health Units (FHU) in two towns in Bahia, Feira de Santana - 7 FHU and Santo Antônio de Jesus - 4 FHU. The first town has a population of 556,642 inhabitants with 86 FHS teams, and the second town has 90,985 inhabitants with 20 teams. The population coverage is $52.23 \%$ and $77.84 \%$, respectively ${ }^{(14)}$.

The participants were 15 nursing team members, including 11 from Feira de Santana (setting 1) and four from Santo Antônio de Jesus (setting 2). Data were collected from October of 2012 to January of 2013. The number of subjects was determined based on theoretical and empirical saturation and repetition of the content represented by the empirical data collected during the data collection process.

Scripts for semi-structured interviews and systematic observation of care were used. Initially, phone contact was made with the FHS teams, using intentional sampling, to schedule the interviews. The interviewed subjects were nurses, technicians and nursing assistants who had been working for more than six months and represented all the health care regions of each town. The observations were performed in ten units, seven in setting 1 and three in setting 2 , totaling 24 hours and 23 minutes. An analyzer flow chart was used for the observations (Figure 1), based on another study ${ }^{(1)}$, in order to facilitate the apprehension of the subjective elements that crossed the delivery of care at different moments of user flow in the family health units.

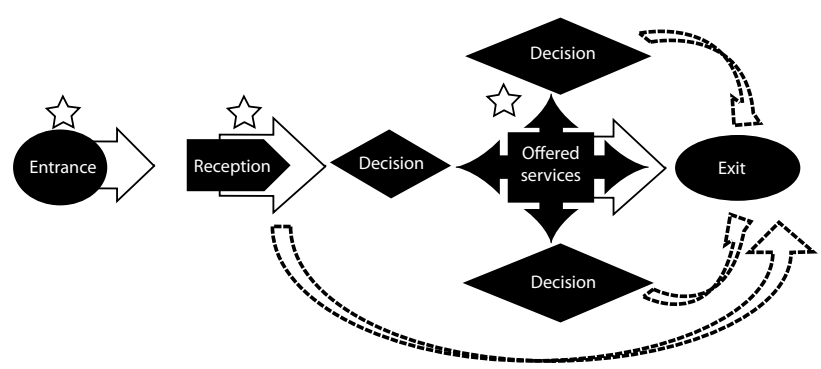

Figure 1 - Flowchart representing the observation of user navigation in the health care service. Feira de Santana and Santo Antonio de Jesus, Bahia, Brazil, 2012-2013.

The representation of the care process in which the nurses are protagonists is shown by the stars and flow of attention to the users, in Figure 1 (entrance, reception, decision, offered services, care decisions, and exiting from the unit). The process is translated into practice by the methods of action, and the ways of intersection between the nursing team professionals and other professionals in the composition of the SUS network. The journey from the moment of entry until exit passes through reception, and encounters the offered services. At that time, decisions are required from the user regarding the way to go. It is noteworthy that these ways include: accepting the path proposed by the service and having their demand referred, or leaving the service without resolving their demand (represented by the dotted arrows).

Thematic content analysis was used as an empirical data analysis strategy (Chart 1$),{ }^{(15)}$. Floating readings were performed to impregnate the content of the field material, followed by vertical synthesis of each unit of analysis, with 
a global view of the set of interviews obtained in the end. Then the relevant structures were identified in the data classification regarding the nursing care process in the FHS and the interfaces with the public health system.

Chart 1 - Analytical framework of the empirical data resulting from interviews and systematic observation in FHS units in Feira de Santana and Santo Antonio de Jesus, Bahia, Brazil, 2012-2013.

\begin{tabular}{|c|c|c|c|}
\hline Thematic units & $\underset{\text { Neam }}{\text { Nursing }}$ & \multicolumn{2}{|c|}{$\begin{array}{l}\text { Horizontal } \\
\text { synthesis }\end{array}$} \\
\hline $\begin{array}{l}\text { 1) NURSE'S ACTION WITHIN THE } \\
\text { CARE PROCESS IN THE SUS NETWORK }\end{array}$ & \multirow{2}{*}{ 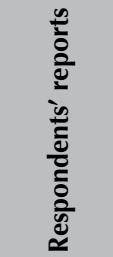 } & \multirow{2}{*}{ 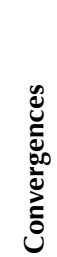 } & \multirow{2}{*}{ 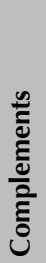 } \\
\hline $\begin{array}{l}\text { 1.1) The nurse, the care process and } \\
\text { its interface with SUS network } \\
1.2) \text { Nursing care in the FHS }\end{array}$ & & & \\
\hline Vertical synthesis & & & \\
\hline
\end{tabular}

First the thematic units were selected, then arranged in analytical frameworks and individually arranged by respondents of both towns. Afterwards horizontal syntheses of the interviews were performed for a better understanding of the essence of the content, relating them with themes separated by towns, which enabled the refinement of the empirical material. In the horizontally synthesis, the convergences and complements were marked. The information on the systematic observation, in turn, was interwoven with the syntheses of the groups in each town. In the final analysis, the data were interpreted and articulated with the theoretical framework of this study, as shown in Figures 2, 3 and 4.

The study was approved by the Research Ethics Committee of the State University of Feira de Santana, Bahia, protocol number $73485 / 12$ protocol, as recommended by Resolution 196/96 of the National Health Council, valid at the time of approval, and authorized by the Municipal Health Secretariats of the studied towns. In addition, all respondents signed the Terms of Free and Informed Consent.

\section{RESULTS}

The flowchart of the SUS care network in the studied settings (Figure 2) shows the possible routes to be followed by the user. It should be noted that nurses act in all routes. The dotted lines represent weaknesses in the care network.

The users' demands can: 1) be resolved in the Family Health Unit itself; 2) be regulated or referred through the Regulation Center, for a policlinic, hospital, tests or specialized consultations. Users can also: 3) seek instructions and referral on their own, or be directed by the team in the Municipal Health Secretariat.

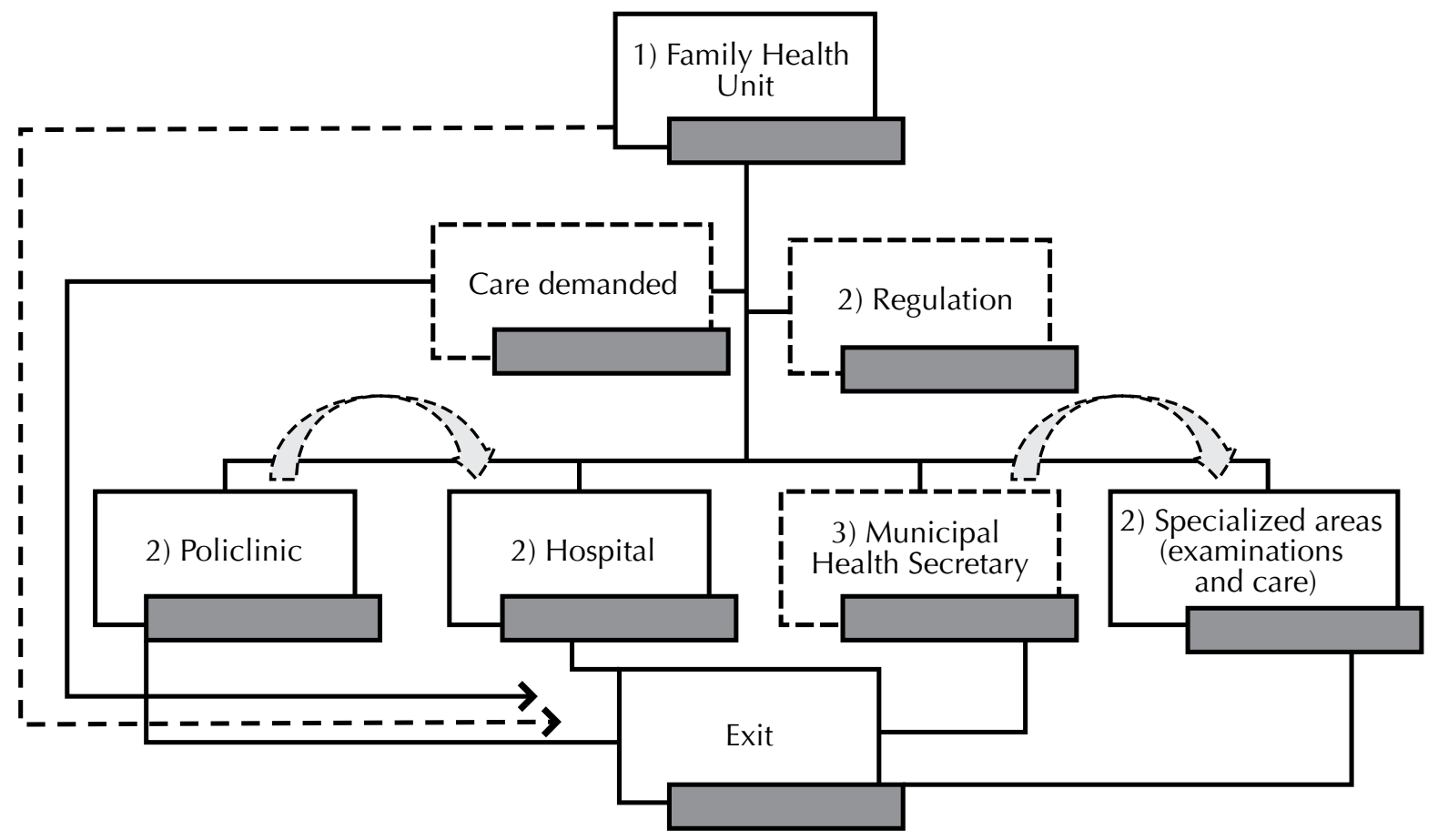

Figure 2 - Flowchart of the users' route for care in the SUS network in Feira de Santana and Santo Antonio de Jesus, Bahia, Brazil, 2012-2013.

A nurse acts in the care process in delivering care activities to a person or social groups/family, and as a member of an education and care management team; s/he instructs and directs users on the way to navigate the health care system. The nurse develops individual and team care, performs home visits, and represents a reference for immunization and wound dressing sectors (Figure 3).

In the educational proposal, the nurse leads health education actions and education in care delivery. In care management, the nurse supervises and coordinates the team (especially the nursing technicians and community health agents), monitors and evaluates the work, organizes meetings with the team, schedules appointments and specialized tests. The nurse also orders unit supplies and maintenance, creates PHC reports, and intervenes in contact with and referrals to the municipal health secretariats. 


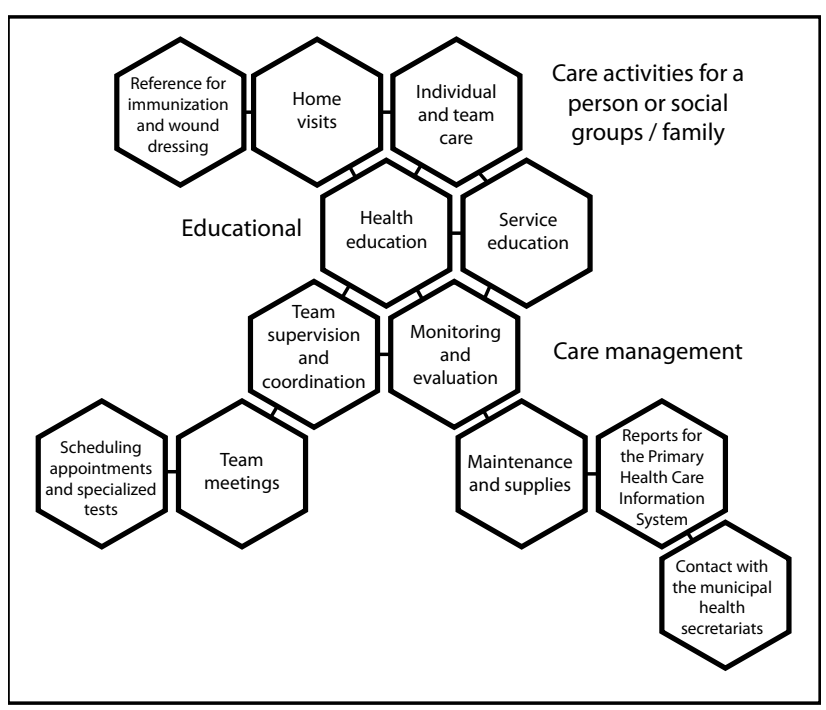

Figure 3 - Actions developed in the nursing care process at the Family Health Unit of Feira de Santana and Santo Antônio de Jesus, Bahia, Brazil, 2012-2013.

The user flow in the service is mediated by the nursing team, which first receives the users in the reception area (in this case, nursing technicians), where they are faced with unscheduled cases, either enabling or prohibiting access by the population.
In addition, within the care management process there is a referral to the offered services and scheduling of a possible return visit, or referral to services with another level of technological complexity.

The reception area is the point of first contact between the team and the user. Therefore, in situations of impossible evaluation or definition of offered services, it is important that there is a space for listening, analyzing and defining the offer based on the health care need, either in providing scheduling, instruction or intervention.

In the empirical field of this research, it was found that there is a centralization by the nurse of the accountability over user referral in the service and in the network. Therefore, the receptionists, mostly nursing technicians, follow the decisions made by the nurses. Although there is a strong presence and effort of the nursing team to resolve the users' demands, there is a lack of training in embracement, which can trigger users' dissatisfaction and exit from the unit without a resolution.

In the observed settings, given the service demands, nurses made an effort to seek solutions for the problems of the users and their families. Despite the effort, it cannot be denied that embracement and user flow had a bureaucratic design. Resolution, ability of care and involvement of the whole team showed up as limited (Figure 4).

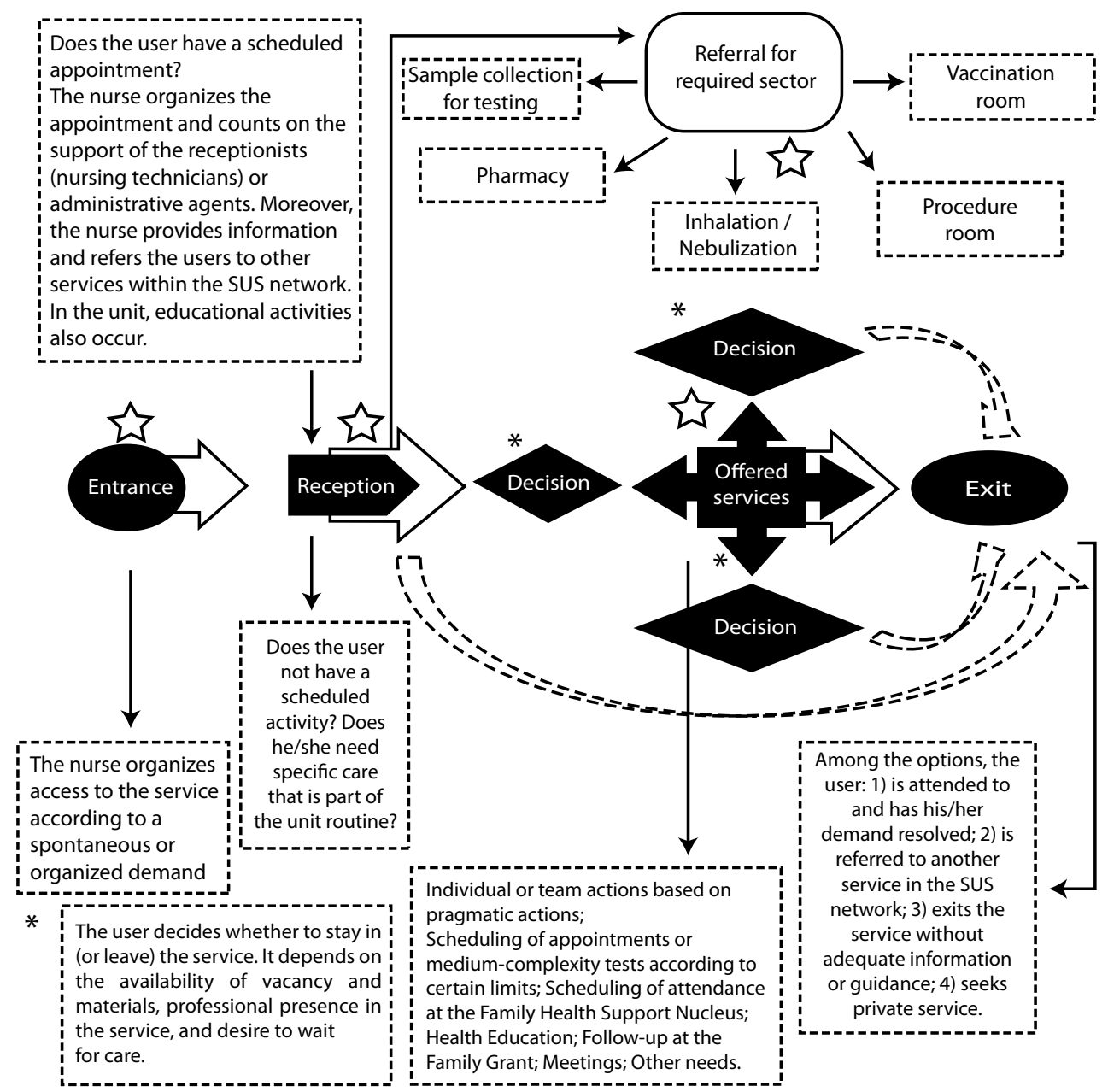

Figure 4 - Flowchart representing the observations of the spaces used by the users, from the nursing care process in the Family Health Units in Feira de Santana and Santo Antônio de Jesus, Bahia, Brazil, 2012-2013. 
The users could have been directed to specific sectors of the FHU: procedure room, immunization, pharmacy, inhalation/nebulization, and collection room. They could also have had access to other offered services: individual care or team care based on programmatic actions, scheduling appointments or medium-complexity test according to certain limits, scheduling of appointments in the Family Health Support Nuclei, health education, follow-up in the Family Grant Program, attending meetings, or other demands. From there, they would exit the service with the possible outcomes, the users: were attended to and had their demand answered; were referred to a SUS network service; left the service without adequate information, service and no instructions, or sought private service (Figure 4).

\section{DISCUSSION}

The data revealed that users were either directed to scheduling and continuity of care or dispensed to the next demand when they sought the unit and had their demand resolved (Figure 2, item 1). At this point, the first weakness is presented, which is the way the user's demand is met within the unit. Lack of professionals, materials and maintenance of the unit structure, as well as the way of caring for the users, with a focus on procedures, weakened the ability to obtain resolution. These occurrences can impact the user, leading to his exiting the service without a team intervention, without instruction and without resolving his need.

From the entrance to this moment, the nurse conducts, directs and plays the role of care coordinator, proving more susceptible to new therapeutic postures ${ }^{(1)}$. In this way, the user can leave the network or (rarely) be returned to the primary unit.

Regulation (Figure 2, item 2) represents another weakness, given the queues and the time required to schedule specialized medical appointments. To ensure access to specialized care, regulation should be improved by ensuring adequate flow to the technologically complex service levels ${ }^{(16)}$.

Another highlight is the organizational and information barriers in the FHS, which can directly impact access to services, as well as embracement of the user. For quality care, there are basic aspects such as convenient open hours, waiting time for service, available professionals, embracement measures and humanization policies, that go beyond the technical quality of care. In addition, information on the health care system, services, diseases and treatment options facilitate the use of the services, because they impact both the health perception of people's health and access to services ${ }^{(17)}$.

Nurses play a largely decisive role in identifying the population's need for care in both promotion and protection of health in its different dimensions in the health care network. Nurses are the first professionals who listen to the users and organize their access to the unit. Similar evidence was identified in other studies ${ }^{(6-8,12)}$, which addressed the FHS team practices focusing on the role of nurses in programmatic activities, home visits and health promotion.

Given the above, it is important to stress the need for ownership of the entire team in the actions aimed at the centrality of the user ${ }^{(1)}$ and his/her ability to be autonomous, without neglecting the care dimension. We suggest the replacement of the decision process centered on a single professional by the involvement of the entire team, which could directly impact care delivery and enhance the establishment of linkages and accountability based on the knowledge and experience of each subject involved in the process ${ }^{(9)}$.

The search for instructions and services by the users in the municipal health secretariats (Figure 2, item 3) is another point of weakness, because it represents an attempt to obtain specialized appointments without a regulation, which can lead to disbelief by the users regarding the care practices developed at the FHS. This occurrence indicates a branched and fluid network, weakness in patient embracement, and low resolution of the users' problems ${ }^{(2)}$.

The strategies of support and education in health are essential to improve embracement by the Family Health Unit. Transforming everyday situations into a pedagogical source demands for the teams to contribute to resolute care and quality ${ }^{(3)}$.

From the mentioned information, it is possible to understand the nurse's role as an agent that mediates and propagates policies and programs in Collective Health. This evidence was also found in other studies ${ }^{(4,6,10-13)}$. For this end, the professional relates with the subjects (users, team and managers) and uses structured knowledge. The care process is still marked by several weaknesses, involving interests, conflicts and needs that confront one another. Interests of politicians and workers in general are always equated to meet the wishes of the parties.

The monitoring and evaluation of this process require communication skills from the nurse, which contribute to the mastery of strategies that resonate with information from other team members and the community, and influence individual and collective decisions from the health promotion perspective ${ }^{(7,9,11-12)}$.

The combination of different tasks represents a greater requirement for training and execution of the work, which causes wear and exhaustion. The versatility of the nurse increases the conflict between what should be done and the time available to perform the activities ${ }^{(8-9)}$. Therefore, the problems are greater than the resources available to solve them, often resulting in anxiety and frustration.

In an ideal service context, the ideal situation would be the reception and guidance of the user without unnecessary delays. Moreover, those in charge of listening to the demands would be able to analyze them, with full knowledge of existing care offered in the health unit, and would be open to dialogue with other workers, with some degree of autonomy to trigger offers according to the times and the considered needs of the user ${ }^{(2)}$.

The influence that the FHS has over the inclusion of users in health care services is remarkable. Nevertheless, there is no denying that as the strategy expands, it triggers important weaknesses that are intrinsic to the changing processes. The professional practices, for example, cannot adequately meet the care needs. Associated with this, in the everyday dynamics of care, management is still processed using strict reasoning, excessive normalization and low managerial ability for 
innovation, which has a direct impact on health actionss ${ }^{(13)}$.

From this discussion, the following reflection emerges: nurses are an important component in health care systems, but they have difficulties delineating the care process and having their potential recognized. Studies show ${ }^{(4,9-10)}$ that elements of the micropolitics in the work process and in the organizational dimensions and macro-structural dimensions make their performance difficult, along with the possibilities of change involving teamwork with shared responsibility among those with different knowledge and practices in the field of Collective Health.

\section{CONCLUSION}

The nursing care process in the health care unit still lacks collective articulation, involving the staff and decentralizing decisions. This would allow for more horizontal relationships and co-responsibility of all those involved in the SUS network and the social spaces at the FHS. The articulation of actions involving knowledge and priorities is desired, from the guidance of individuals with ability for analysis and comanagement of their lives and institutions.

Management and professional practices have the ability to change the subjects and patterns of subjectivity. It is necessary to break with the dominant mode of intervention in the health care area and enable the construction of new modes of care delivery, which value both professionals' and users' subjectivity.

The robustness in everyday dynamics of care can only be recognized and designed in its entirety by means of a collective action, in a situation in which all subjects are participants in the process. It must start from recognition of the need for the work of all and the division of tasks at all levels of technological density of the health care network. Added to this, it is relevant to discuss the specific aspects of the organization and the work process. The user's position as a passive subject of the system needs to be overcome.

The nursing care process and its interfaces with the SUS network evidenced here deal with weaknesses of different instances, such as: political scenario, layoffs, lack of professionals in the network, precarious employment relationships, among others, that would justify the situation.

The valuing of the relational field and intersubjectivity, with regard to the needs of users, will enable the connection of health care practices in the network, i.e., teams with teams. After all, an integrated network requires new managerial modes with institutional democracy, participation of subjects and commitment with SUS.

Regarding the limitations of this study, we cite the analysis from the perspective of the nursing team, a relatively homogeneous group, which can indicate circumscribed representations to their knowledge and practices.

\section{RESUMO}

Objetivo: Analisar o cuidado produzido pela enfermeira na Estratégia Saúde da Família e suas interfaces com a rede do Sistema Único de Saúde em suas fragilidades e potencialidades. Método: Pesquisa de abordagem qualitativa realizada mediante entrevistas semiestruturadas e observações sistemáticas, com a participação da equipe de enfermagem, composta por 15 pessoas, no período de outubro de 2012 a janeiro de 2013. Resultados: Revelaram como potencialidades: a polivalência da enfermeira na condução dos usuários na unidade, e na rede de saúde, sendo assim, atua diretamente no acesso desses aos serviços. É o principal sujeito que participa dos processos de cuidar em atenção à pessoa, família e grupos sociais. Como fragilidades destacam-se o acolhimento frágil e a baixa resolubilidade em relação aos problemas apresentados pelos usuários e famílias. Conclusão: O processo de cuidar da enfermeira na unidade de saúde ainda carece de articulação coletiva, envolvendo a equipe e descentralizando as decisões.

\section{DESCRITORES}

Cuidados de Enfermagem; Estratégia Saúde da Família; Acesso aos Serviços de Saúde; Sistema Único de Saúde; Enfermagem em Saúde Pública.

\section{RESUMEN}

Óbjetivo: Analizar el cuidado producido por la enfermera en la Estrategia Salud de la Familia y sus interfaces con la red del Sistema Único de Salud en sus fragilidades y potencialidades. Método: Investigación de abordaje cualitativo realizado mediante entrevistas semiestructuradas y observaciones sistemáticas, con la participación del equipo de enfermería, compuesto de 15 personas, en el período de octubre de 2012 a enero de 2013. Resultados: Revelaron como potencialidades: la polivalencia de la enfermera en la conducción de los usuarios en la unidad, y la red de salud, demostrando su actuación directa en el acceso de los pacientes a los servicios. Es el principal sujeto que participa de los procesos de cuidar en atención a la persona, familia y grupos sociales. Como fragilidades se destacan la acogida frágil y la baja resolubilidad con relación a los problemas presentados por los usuarios y familias. Conclusión: $\mathrm{El}$ proceso de cuidar por parte de la enfermera en la unidad de salud todavía carece de articulación colectiva, implicando al equipo y descentralizando las decisiones.

\section{DESCRIPTORES}

Atención de Enfermería; Estrategia de Salud Familiar; Accesibilidad a los Servicios de Salud; Sistema Único de Salud; Enfermería en Salud Pública.

\section{REFERENCES}

1. Amorim ACCLA, Assis MMA, Santos AM, Jorge MSB, Servo MLS. Practices of the Family health team: advisors of the access to the health services? Texto Contexto Enferm. 2014;23(4):1077-86.

2. Mendes EV. As redes de atenção à saúde. Ciênc Saúde Coletiva. 2010;15(5):2297-305. 
3. Assis MMA. Poliarquia ou hierarquia nas redes de atenção à saúde? Inovação Gerencial. In: Cunha FJAP, Lázaro CP, Pereira HBB, organizadores. Conhecimento, inovação e comunicação em Serviços de Saúde. Rio de Janeiro: FIOCRUZ; 2014. p. 133-53.

4. Matumoto S, Fortuna CM, Kawata LS, Mishima SM, Pereira MJB. Mapping pain in the clinical practice of nurses within Primary Health Care. Texto Contexto Enferm [Internet]. 2013 [cited 2014 Jan 20];22(2):318-26. Available from: http://www.scielo.br/pdf/tce/v22n2/en_ v22n2a07.pdf

5. Kawata LS, Mishima SM, Chirelli MQ, Pereira MJB, Matumoto S, Fortuna CM. Attributes mobilized by nurses in family health: reaching performances when developing managerial competence. Rev Esc Enferm USP [Internet]. 2011 [cited 2014 Jan 20];45(2):349-55. Available from: http://www.scielo.br/pdf/reeusp/v45n2/en_v45n2a06.pdf

6. Backes DS, Souza MHT, Marchiori MTC, Colomé JS, Backes MTS, Lunardi Filho WD. The Idealized Brazilian Health System versus the real one: contributions from the nursing field. Rev Latino Am Enfermagem. 2014;22(6):1026-33.

7. Zenzano T, Allan JD, Bigley MB, Bushardt RL, Garr DR, Johnson K, et al. The roles of healthcare professionals in implementing clinical prevention and population health. Am J Prev Med. 2011;40(2):261-67.

8. Roecker S, Nunes EFPA, Marcon SS. The educational work of nurses in the Family Health Strategy. Texto Contexto Enferm. 2013;22(1):15765.

9. Souza MG, Mandu ENT, Elias NA. Perceptions of nurses regarding their work in the Family Health Strategy. Texto Contexto Enferm [Internet]. 2013 [cited 2014 Jan 20]; 22(3):772-79. Available from: http://www.scielo.br/pdf/tce/v22n3/en_v22n3a25.pdf

10. Bellaguarda MLR, Padilha MI, Pereira Neto AF, Pires D, Peres MAA. Reflexão sobre a legitimidade da autonomia da enfermagem no campo das profissões de saúde à luz das ideias de Eliot Freidson. Esc Anna Nery [Internet]. 2013 [citado 2014 jan. 20];17(2):369-74. Disponível em: http://www.scielo.br/pdf/ean/v17n2/v17n2a23.pdf

11. Fortuna CM, Matumoto S, Camargo-Borges C, Pereira MJB, Mishima SM, Kawata LS, et al. Cartographic notes on the work in the Family health strategy: relationships between workers and the population. Rev Esc Enferm USP [Internet]. 2012 [cited 2014 Jan 20]; 46(3): 657664. Available from: http://www.scielo.br/pdf/reeusp/v46n3/en_18.pdf

12. Sá LD, Gomes ALC, Carmo JB, Souza KMJ, Palha PF, Alves RS, Andrade SLE. Educação em saúde no controle da tuberculose: perspectivas de profissionais da Estratégia Saúde da Família. Rev Eletr Enf [internet]. 2013 [citado 2015 mar. 17];15(1):103-11. Disponível em: http:// revistas.ufg.br/index.php/fen/article/view/15246

13. Santos JLG, Pestana AL, Guerrero P, Meireles BSH, Erdmann AL. Práticas de enfermeiros na gerência do cuidado em enfermagem e em saúde: revisão integrativa. Rev Bras Enferm. 2013;66(2):257-63.

14. Brasil. Ministério da Saúde. DATASUS. Cadastro Nacional de Estabelecimentos de Saúde. Estabelecimentos por Nível de Atenção [Internet]. Brasília, 2014 [citado 2014 jan. 21]. Disponível em: http://tabnet.datasus.gov.br/cgi/deftohtm.exe?cnes/cnv/atencba.def

15. Assis MMA, Jorge MSB. Métodos de análise em pesquisa qualitativa no campo da saúde. In: Santana JSS, Nascimento MAA, organizadoras. Pesquisa: métodos e técnicas de conhecimento da realidade social. Feira de Santana: UEFS; 2010. p.139-59.

16. Albuquerque MSV, Lima LP, Costa AM, Melo Filho DA. Regulação assistencial no Recife: possibilidades e limites na promoção do acesso. Saúde Soc [Internet]. 2013 [citado 2015 mar.17 mar];22(1):223-36. Disponível em: http://www.scielo.br/pdf/sausoc/v22n1/20.pdf

17. Assis MMA, Jesus WLA. Acesso aos serviços de saúde: abordagens, conceitos, políticas e modelo de análise. Ciên Saúde Coletiva. 2012;17(11):2865-75. 